\title{
FORUM
}

Submitted 11.29.2013. Approved 05.14.2014

Evaluated by double blind review process. Scientific Editors: Edgard Barki, Graziella Comini, Ann L Cunliffe, Stuart Hart and Sudhanshu Rai

DOI: http://dx.doi.org/10.1590/So034-759020150404

\section{MICROFINANCE AND CLIMATE CHANGE IMPACTS: THE CASE OF AGROAMIGO IN BRAZIL}

\author{
Microfinanças e impactos das mudanças climáticas: o caso do Agroamigo no Brasil \\ Microfinanza y los impactos de los cambios climáticos: el caso del \\ Agroamigo en Brasil
}

\begin{abstract}
This paper reports an empirical case study on the interface between microfinance and climate change actions. Climate change, which until recently seemed a luxury for the microfinance sector, now appears to be crucial for its future. For their low adaptive capacity, the millions of microfinance clients worldwide happen to be the most vulnerable to a changing climate. However, such an arena is still blurred from an academic viewpoint, and inexistent among Brazilian academia. Therefore, by investigating Brazil's largest rural MFI, Agroamigo, we aim at providing an empirical contribution to green microfinance. The main conclusion is that, albeit Agroamigo offers important links to climate change initiatives, it will need to take better account of specific vulnerabilities and risks to protect its portfolio and clients better from climate change impacts.
\end{abstract}

KEYWORDS | Green microfinance, climate change, Pronaf, vulnerability, Agroamigo.

\section{RESUMO}

Este artigo relata um estudo de caso empírico sobre a interface entre as microfinanças e temáticas da mudança do clima. Tais temáticas que até recentemente pareciam um luxo para o setor, agora parecem ser cruciais para o seu futuro. Coincidentemente, pela baixa capacidade adaptativa, os clientes microfinanceiros mundo afora estão entre os mais vulneráveis à mudança do clima. No entanto, tal arena é ainda pouco conhecida pela academia e inexistente no discurso acadêmico brasileiro. Portanto, investigando o maior programa de microfinança rural do Brasil, Agroamigo, o presente estudo tem por objetivo prover uma contribuição empírica para as microfinanças verdes. A principal conclusão é que, embora Agroamigo ofereça importantes sinergias com iniciativas da mudança climática, ele terá de levar mais em consideração vulnerabilidades e riscos específicos para melhor proteger o seu portfólio e clientes dos impactos advindos das mudanças climáticas.

PALAVRAS-CHAVE / Microfinanças verdes, mudanças climáticas, Pronaf, vulnerabilidade, Agroamigo.

RAFAEL MAGNUS BARBOSA MOSER rafaelmoser@hotmail.com Master's in European and International Studies from the Scuola di Studi Internazionali, Università degli Studi di Trento - Trento - Italy

\section{LAURO GONZALEZ}

lauro.gonzalez@fgv.br

Professor at Fundação Getulio Vargas, Escola de Administração de Empresas de São Paulo - São Paulo - SP, Brazil

\section{RESUMEN}

Ese artículo presenta un estudio de caso empírico sobre la interrelación entre microfinanza y acciones de cambio climático. El cambio climático, que hasta recientemente parecía un lujo para el sector de microfinanzas, ahora parece ser crucial para su futuro. Por su baja capacidad adaptativa, los millones de clientes de microfinanzas alrededor del mundo son los más vulnerables a un clima cambiante. Sin embargo, dicha área aún está borrosa desde un punto de vista académico e inexistente entre la academia brasileña. Por lo tanto, al investigar el mayor MFI?? de Brasil, Agroamigo, pretendemos proveer un aporte empírico a la microfinanza ecológica. La conclusión principal es que no obstante el Agroamigo ofrezca vínculos importantes a las iniciativas sobre el cambio climático, necesitamos tener mejor en cuenta los riesgos y vulnerabilidades específicas para proteger mejor su portfolio y clientes de los impactos del cambio climático.

PALABRAS CLAVE I Microfinanza ecológica, cambio climático, Pronaf, vulnerabilidad, Agroamigo. 


\section{INTRODUCTION}

Over the last few decades, a great deal has been written about the importance of microfinance (MF) in promoting financial access to the world's poor, as well as an effective tool in achieving Millennium Development Goals (MDGs) (Littlefield, Morduch, \& Hashemi, 2003). Such attractive MF attributes, however, could be jeopardised if predictions of the Intergovernmental Panel on Climate Change (IPCC) about global warming and associated changes in Earth's climate pattern come true. According to the IPCC (2013), toward the end of the $21^{\text {th }}$ century, global mean temperatures are projected to range between a best case [low-carbon economy model] of $1^{\circ} \mathrm{C}$ and a most stringent case scenario [carbon intensive economy model] of $3.8^{\circ} \mathrm{C}$, with some climatologists arguing that $1.5^{\circ} \mathrm{C}$ is the least realistic increase we can expect. In Brazil, alone, a gradual increase in mean temperatures varying between 1 and $6^{\circ} \mathrm{C}$ is expected in the course of the century (Painel Brasileiro de Mudanças Climáticas [PBMC], 2013). In spite of such differences in temperature outcomes, scientists do agree that a warmer planet will bring profound transformations in the climate system as we know it today.

As a result, the changing climate "will impact individuals at the most basic level" (United States Agency for International Development [USAID], 2009, p. 2), and will fall unevenly among regions, with less-developed countries facing the greatest risks (IPCC, 2013). Therefore, poor countries and persons in the global south will bear the worst consequences of climate change and its associated disturbances (Bretschger \& Valente, 2011; Schellnhuber et al., 2013). In addition, global warming is projected to lower the level and growth of GDP and thus increase poverty, undermining progress towards achievement of the MDGs (Stern, 2007). "Like everything else, microfinance will not be spared" (Rippey, 2012, p. 215).

In fact, global climate change will affect microfinance institutions (MFIs) and their clients in myriad ways. For example, increased incidence of droughts, flooding, storms, extreme weather events, as well as rising sea levels are very likely to endanger assets-such as homes, crop yields, micro-businesses, and livestock - of many MF clients worldwide, and thus, undermine their ability to repay loans (Dowla, 2009). In addition, decline in quality and quantity of water sources compounded with increased incidence of vector-borne diseases because of climate change may affect clients' health, and thus, indirectly affect an MFl's portfolio. Greater stress on natural resources in extreme climate areas may also lead to forced migration and perhaps impact several MFIs and clients in these regions. Furthermore, natural disasters and extreme events are very likely to have a direct impact on physical infrastructure-such as equipment, offices, records and information systems-of several MFIs (Dowla, 2009). Ultimately, if no coping strategy is put in place, climate change may well affect, both directly and indirectly, the portfolio of many microfinance providers.

The marriage of microfinance with climate change is particularly relevant to Brazil. From a climate change perspective, Brazil is both a major international actor in the fight against climate change and a major victim of its adversities (see, for instance, Loiselle et al., 2010; Marengo, Alves, \& Valverde, 2009). In a 22-year timeframe (1990-2012), greenhouse gas (GHG) emissions from Brazil have increased by $7 \%-$ with land-use change [in particular, deforestation], fossil-fuel burn, and the agricultural sector as the main contributors (Sistema de Estimativa de Emissões de Gases de Efeito Estufa, 2014)-, ranking Brazil seventh among the world's largest emitting countries (Teixeira, 2013), and consequently, as a central player in terms of climate change actions.

Such an increase in anthropogenic GHG emissions was sufficient to ignite extreme climatic events in most Brazilian regions that caused significant life and asset losses. Through 1991 and 2010, for instance, more than 96 million Brazilians were affected by climate-related disasters, in particular throughout Brazil's Northeast (Centro Universitário de Estudos e Pesquisas sobre Desastres-Universidade Federal de Santa Catarina [CEPED-UFSC], 2012). Temperatures increase over the $21^{\text {th }}$ century, the ever-changing climate will bring further natural and socioeconomic impacts to Brazil.

On the other hand, favoured by governmental actions, microfinance in Brazil has experienced a big boom over the last decade (Gonzalez, Piza, \& Garcia, 2009). The sector saw its lending capacity and number of clients served increase considerably, peaking at US $\$ 2.5$ billion and US\$2.7 million in 2013, respectively (Mix Market, 2014). And yet, with 44 million people still working in the informal sector and some 10 million informal microenterprises lacking access to credit in the country (Serviço Brasileiro de Apoio às Micro e Pequenas Empresas [SEBRAE], 2010), much of its potential remains untapped. Accordingly, when these two realms combine they offer an attractive and overlooked vehicle to deliver climate change strategies to the poorest segments of Brazil's society.

To date, however, academia has drawn little attention as to the impact of climate change on MFIs and their clients. By combining a priori uncorrelated realms the article aims to contribute to awareness raising and research on such a promising and, contemporarily, underdeveloped field, having Brazil as a case study. More specifically, guided by the general questions: What is the interface between products offered by an MFI and climate change actions?, and what actions can be bolstered to take better consideration of climate change vulnerabilities?, the study aims to 
provide an empirical and contextualised assessment of the links between a Brazilian microfinance provider and localised climate change initiatives. This paper is, in fact, the first in Brazil that seeks to assess eventual synergies empirically between these two realms, and as such, served as impetus for our investigation.

To do so, we applied a case study on the largest rural microcredit programme in Brazil, namely Agroamigo. The Programme was founded in 2005 as a rural microfinance pilot project aimed at improving the socioeconomic conditions of smallholder farmers across Brazil's Northeast, which accounts for over $82.9 \%$ of the regional rural labour force (Banco do Nordeste, 2013), and is directly related to food security issues. It also sought to minimise excessive default rates, as high as $37 \%$, which the Programa Nacional de Fortalecimento da Agricultura Familiar (Pronaf [National Programme for Strengthening Family Farming]) faced when lending to poorest segments of rural communities in the region.

Since then, with an average default rate of $3.26 \%$, Agroamigo has evolved considerably both in terms of number of borrowers and outstanding loan portfolio. In fact, in 8 years, Agroamigo has provided about US\$2 billion in 2.3 million microloans through its 170 branches covering over 1,954 municipalities throughout North-eastern states as well as Minas Gerais (Banco do Nordeste, 2013). In 2013, alone, it operated 421,482 microloan contracts, averaging US\$1,300 per loan, and amounting over US\$562,000, remaining unrivalled as Brazil's largest rural microfinance programme.

The remainder of the study is structured as follows. In section two, we review the handful of authors investigating green microfinance and the fusion of microfinance with climate change. Next, we provide the methodological approach applied to this empirical study, followed by a discussion of the analysis. Finally, in the last section we draw some recommendations.

\section{LITERATURE REVIEW}

Albeit there is limited literature addressing the topic, the fusion of microfinance with climate change offers a compelling case for action. As Rippey (2012) put it, it is no coincidence that a year after Muhammed Yunus was awarded the Nobel Peace Prize for his commitments in fostering socioeconomic development from below, the same happened to the IPCC for its work on climate change. For many decades, climate change seemed a "luxury" that the microfinance industry could not afford or dream of (McKee, 2008, p. 35). However, the last decade witnessed a growing perception that "incorporating a climate change lens to microfinance is essential and urgent" [...] "as well as critical to the future of the sector" (McKee, 2008, p. 37). In fact, for their low adaptive capacity, the millions of microfinance clients globally are the most vulnerable to climate variability (Ahmed, Diffenbaugh, \& Hertel, 2009; Stern, 2007) and their "plight is linked to the ability of MFIs to adapt to the consequences inflicted by climate change" (Dowla, 2009, p. 5).

In this light, green microfinance can be thought of as microfinance products coupled with adaptation to and mitigation of climate change. Adaptation refers to adjustments in natural or human systems in response to actual or expected climatic stimuli or their effects, with a view of moderating harms or exploiting benefits and opportunities associated with climate change (Brooke, 2008). In turn, mitigation involves human interventions to reduce GHG emissions by sources and/or enhance their removal from the atmosphere by “sinks"-forests, oceans, and plants absorbing $\mathrm{CO}_{2}$ (Vijayavenkataramana, Iniyan, \& Goic, 2012).

To date, though, MFI initiatives have focused primarily on GHG mitigation via financing of cleaner/renewable energy sources (Agrawala \& Maëlis, 2010; McKee, 2008; Rippey, 2012). For example, since 2006, SEWA Bank, in partnership with SELCO-India, has offered loans for solar lighting, bio-digesters and improved cooking stoves to its members (McKee, 2008). Since 1996, Grameen Shakti, a Grameen Bank's affiliate, has provided about 2.5 million people with affordable solar energy system loan schemes (Majumber, 2009). Further, a partnership between HSBC, Spandana and MicroEnergy Credits, has facilitated access to affordable solar-powered lighting to about 1 million poor people via the selling of resulting carbon offsets on the international voluntary market (Allet \& Hudon, 2013).

Microfinance institutions also offer an attractive vehicle to deliver adaptation at the customer level. The few studies combining microfinance and adaptation (see, for example, Agrawala \& Maëlis, 2010; Hall, Collins, Israel, \& Wenner, 2008; Hammill, Matthew, \& McCarter, 2008) argue that MFIs, through the combination of both financial and non-financial services, can increase clients' adaptive ability by helping them accumulate assets and diversify income sources, as well as coping mechanisms over time [e.g. savings and microinsurance]. They can also share knowledge and information to influence their behaviour. In addition, MFIs can be used as distributional channels for donors to deliver adaptation to millions of poor people worldwide, especially women, who are particularly vulnerable to climate change impacts (Agrawala \& Maëlis, 2010; Hammill, Matthew, \& McCarter, 2008).

To our knowledge, the sole green microfinance institution idealised specifically for adaptation is the Micro-Insurance Facility (MIF) in Cambodia. Through a revolving fund, the community-led project provides productive microloans to poor rural women and all related dividends and reserve funds are reinvested in rice stock as a protection mechanism against harvest shocks and food shortage. Forcella (2011) argues that, albeit some adjustments need 
to be considered, the MIF helped increase the community's resilience to cope with natural disasters mainly by fostering savings and local project ownership, building up the clients' asset base and promoting diversification of income sources.

Also, at the $\mathrm{MFI}$ /institutional level there are several ways in which microfinance providers can promote both adaptation and mitigation. For instance, management can assess an MFl's carbon footprint in order to estimate its impact in terms of GHGs emissions and, upon that, devise carbon-offsetting strategies (Hall et al., 2008). MFIs can also promote risk assessment plans in order to respond better to and benefit from climate change. Further, they can strengthen personnel capacity to deal with climate change through training activities (Rippey, 2012).

Nonetheless, there remain trade-offs to consider in microfinance actions in terms of climate change. While microfinance seems to thrive in the provision of financial and non-financial services to the active poor, it struggles to reach the poorest of the poor (Cull, Dermigüç-Kunt, \& Morduch, 2009, p. 179), which are, after all, the most vulnerable to climate change. Also, MFIs will need to weigh the balance between short-term livelihood needs of clients and long-term commitments needed for adaptation and mitigation (Hammill, Matthew, \& McCarter, 2008; Rippey, 2012). Additionally, as the 2010 crisis in India's southern state of Andhra Pradesh revealed, microcredit may end up increasing the debt burden of customers (Taylor, 2012), placing added pressure on their adaptive ability (Hammill, Matthew, \& McCarter, 2008). Besides, climate change actions at the customer and $\mathrm{MFI}$ /institutional level may also entail risks for MFIs' portfolio as they seek to adapt products and forge new competencies in terms of adaptation and/or mitigation (Rippey, 2012). Lastly, a "climate-proof" MFI would require additional skills and capacities that many MFIs, especially the smallest ones, simply lack. Therefore, MFIs in responding to climate change will need to balance between costs and benefits entailed in fostering climate change strategies, as well as keep expectations realistic as microfinance actions in this terrain are certainly no panacea.

\section{METHODOLOGICAL APPROACH}

This study seeks to replicate previous analysis derived from Agrawala and Maëlis (2010) in Nepal and Bangladesh to the Brazilian context. More specifically, it seeks to examine potential synergies between products and programmes offered by a Brazilian MFI and localised adaptation/mitigation strategies as well as assess what strategies can be harnessed to take better considerations of localised climate change vulnerabilities. To address our research questions, this study relied on a qualitative approach and on the triangulation of methodological techniques to offset eventual biases (Berg, 2004; Moran-Ellis et al., 2006). Among these were field observation, documentation, interviewing, and case study.

In order to facilitate understanding and provide insight into our subject matter, we applied a single instrumental case method as designed by Stake (2005). According to Robert Stake $(1995,2005)$, by putting emphasis on a holistic treatment of a particular phenomenon, instrumental case studies serve the purpose of advancing knowledge of a specific topic under scrutiny (Stake, 1995, 2005). The selected case was Agroamigo of the Banco do Nordeste do Brasil (BNB), the largest rural microfinance programme in Brazil. We believe that Agroamigo offers an interesting context for research on the combination of microfinance with climate change because, on the one hand, it finances highly climate-sensitive activities such as agricultural products and, on the other, it operates in one of Brazil's most vulnerable regions for extreme climatic events, i.e. the Northeast region. In fact, through 2012-2013 the Northeast was stricken by the worst droughts in 50 years, inflicting several losses to poor smallholder farmers (United Nations, 2013).

\section{Data collection}

The article draws on a variety of information and data stemming from different sources: financial reports, interviews, and field observation. During four months the authors collected, processed and analysed relevant data at the Centro de Estudos em Microfinanças (CEMF [Centre for Microfinance Study]) of the Fundação Getulio Vargas in São Paulo/Brazil. In particular, this study has reviewed forty-six programmes, products and services from Agroamigo's annual financial reports in recent years, usually for 2010-2013. A list of products was then built and further confirmed during field research and interviews. Second, we sought to analyse such products in light of the theory guiding green microfinance to assess eventual synergies between climate change actions and Agroamigo's products before, finally, drawing some conclusions. In addition, data from the Mix Market platform was also used for the purpose of this research.

During the design and preparation of the field research and interviews, we identified five main social groups within Agroamigo considered relevant for our investigation. These include national programme managers, regional programme managers, coordinators, credit agents and clients. National programme managers are responsible for the general supervision of Agroamigo's branches in all states in which it operates as well as for the setting up of business strategies. Regional programme managers are responsible for the supervision of regional and local units. Coordinators 
are charged with specific areas in the surroundings of an Agroamigo's branch and they supervise local credit agents. Credit agents, in turn, are the point of contact between clients and Agroamigo, as well as responsible for credit information, contract analysis, and so forth. Lastly, clients are smallholder farmers, often very poor, who benefit from rural micro-lending and other services.

This process was followed by an on-site field study at Agroamigo headquarters and in inland/coastal Ceará whereby we carried out interviews and field observations as well as collected further documents. Three localities spread over the state of Ceará were chosen for the application of interviews: Poço da Pedra located in inland Ceará, a rural community within the municipality of Canindé, one of the most arid regions of the state; on the coastal area, the municipality of Icapuí, a poor rural village; and, the Agroamigo's headquarters in Fortaleza, the capital of the State. During the field research, we also had the opportunity to attend an informative session held by credit agents and dedicated to prospective clients in the rural community of Poço da Pedra as well as the "Tribute to Nature" event hosted by local Agroamigo staff in the village of Icapuí.

Twenty-one respondents were selected in loco based on their belonging to specific social groups and availability to participate in the interviews. Accordingly, two national managers, one regional manager, two coordinators, six credit agents, and twelve clients were interviewed. For each social group we applied a specific questionnaire pertinent to their activities, experiences and contextual perception of our subject matter. For instance, to national and regional programme managers we posed questions related to the overall design, administration, and performance of Agroamigo's products as well as questions related to the performance of such products during hazardous weather events-e.g. programmes aimed to reduce client vulnerability ahead of extreme climatic events; coping mechanisms against losses arising from such events, and so forth. To coordinators and credit agents we sought to design questions that better reflected their perceptions and experiences regarding the performance of products during extreme weather events. For instance, perception about exposure of clients to drought events and how Agroamigo usually reacts with weather-related losses faced by clients. Lastly, to clients we designed questions associated to their own experiences vis-à-vis actual impacts of climatic events on their rural activities, for example, by asking whether they have already suffered drought-related losses; how they usually deal with such shocks; and whether they received disaster relief aid from Agroamigo. Interview length varied from fifteen minutes, for clients, to one hour for managers.

After reviewing documentation and transcribed data from interviews, we identified the most relevant localised climate change impacts for Agroamigo and its clients. Then, we clustered the forty-six programmes and products offered by Agroamigo and reviewed by this analysis into specific categories to reflect sector finance activities better. Among these are: forestry, employment and income generating activities in agricultural/livestock as well as in the non-agricultural sector, water/disaster relief/preparedness, education, technical assistance/information transfer, health, and savings schemes.

Next, we proceeded with the analysis of links between Agroamigo's products and site-specific climate change impacts, as suggested by Agrawala and Maëlis (2010). More specifically, we compiled the data into four categories: indirect link, direct link, climate proofing, and no link. The first refers to activities which, albeit not explicitly aimed at adaptation/mitigation, have positive impacts on the livelihood of clients as they either help them diversify income sources, accumulate assets, and/or promote employment creation and, as such, would naturally enhance their adaptive ability. Activities that explicitly consider adaptation/mitigation strategies fall into the direct link. Climate proofing, meanwhile, refers to those programmes that may need adjustments to take better account of site-specific climate change vulnerabilities. Lastly, no link activities, as the name suggests, have neither direct nor indirect connection with adaptation/mitigation to climate change. It is noteworthy that, in particular cases, a programme may fall into different categories.

\section{Analysis and discussion of results}

In this section we seek to introduce the context in which Agroamigo operates before addressing and presenting our analysis and related results.

\section{Agroamigo: Geographic context, products, and climate change vulnerabilities}

Most of the villages where Agroamigo operates are characterised by semiarid climate and covered by caatinga, an endemic, semiarid climate biome. Average annual precipitation in those regions is $700 \mathrm{~mm}$ and evapotranspiration losses are three times as high as annual rainfalls (Silva et al., 2012). They also have high spatial and temporal rainfall variability with roughly $80 \%$ of total annual precipitation concentrated around 4 months. Statistically, the Northeast has reported between 18 and 20 years of droughts per century, with the last century the driest ever recorded (Marengo \& Valverde, 2007).

For its climate specificities and its harsh socioeconomic conditions, the Northeast Region is in the frontline of climate change as one of Brazil's most vulnerable areas to a changing climate (Baettig, Wild, \& Imboden, 2007). Surface air tempera- 
tures, for instance, are projected to increase and rainfalls to decrease substantially during the XXI century compared to past trends. Accordingly, temperatures are likely to increase by $0.5^{\circ} \mathrm{C}$ and $1^{\circ} \mathrm{C}$ and rainfalls to decrease by $10 \%$ and $20 \%$ until 2040 . Between 2041 and 2070, the climate in the region is projected to get even warmer, up $1.5^{\circ} \mathrm{C}$ to $2.5^{\circ} \mathrm{C}$, and precipitation is expected to drop by between $25 \%$ and $35 \%$. Toward the end of the century, temperatures are likely to rise by $3 \cdot 5^{\circ} \mathrm{C}$ to $4.5^{\circ} \mathrm{C}$, whereas rainfall distribution will decrease markedly between $40 \%$ and $50 \%$ (PBMC, 2013). As a result, there will be a significant reduction in water supply, reaching $100 \%$ by the end of the century (Marengo et al., 2012).

Other changes in the climate pattern predicted for Brazil's Northeast include: drier air and increase in the number of consecutive dry days; reduction in extreme rainfall events leading to increased frequency of droughts; increased evapotranspiration; decreased river runoff; and, eventual rise in sea level in coastal areas, especially in the city of Recife (Marengo \& Valverde, 2007, Muehe, 2006). Such changes in climate patterns are likely to trigger major natural and socioeconomic impacts across Northeastern Brazil.

Exhibit 1 ranks key site-specific climate change impacts and vulnerabilities for the Northeastern region based on scientific projections and on responses by interviewees. Significant among these are variables related to water resources/access and agriculture/livestock, ranked at the top, as being of highest priority in terms of socioeconomic impacts as well as urgency. Added pressure on water access and irrigation, reduction in arable land caused by desertification, and associated decrease in agricultural yields will substantially affect the Region's rural population as they rely greatly on such resources for their livelihoods. In fact, during interviews all five social groups argued that water scarcity already constitutes a major challenge for rural activities in the region, in particular during extreme drought periods. For all interviewed clients, the lack of quality water for consumption and for rural activities was perceived as the major threat to sustain their businesses, especially for those clients raising livestock. For two interviewed smallholder farmers, this was the primary cause of total harvest loss during the 2012-2013 intense droughts.

Human Health is ranked next mainly due to the expected increase in vector-borne diseases because of climate change as well greater stress on water access. Some clients emphasised that at least one member of their household has already had health issues due to tropical diseases and/or poor quality water. This is followed by energy generation in particular because a reduction in river runoff would pose significant threats on the regional energy matrix, markedly reliant on hydropower. In fact, as a side effect of the recent large-scale drought, in February 2014, costly and polluting thermoelectric generators needed to be activated to offset lowering energy production of hydroelectric plants in the region (Warth, 2014). Lastly, forced migration flows, a historical burden on the Northeast's semiarid population, would increase considerably as social, economic conditions deteriorate in the incidence of intensified climatic events, and thus is ranked next.

\section{Exhibit 1. Resource ranking of key climate change priorities and vulnerabilities for Brazil's Northeast}

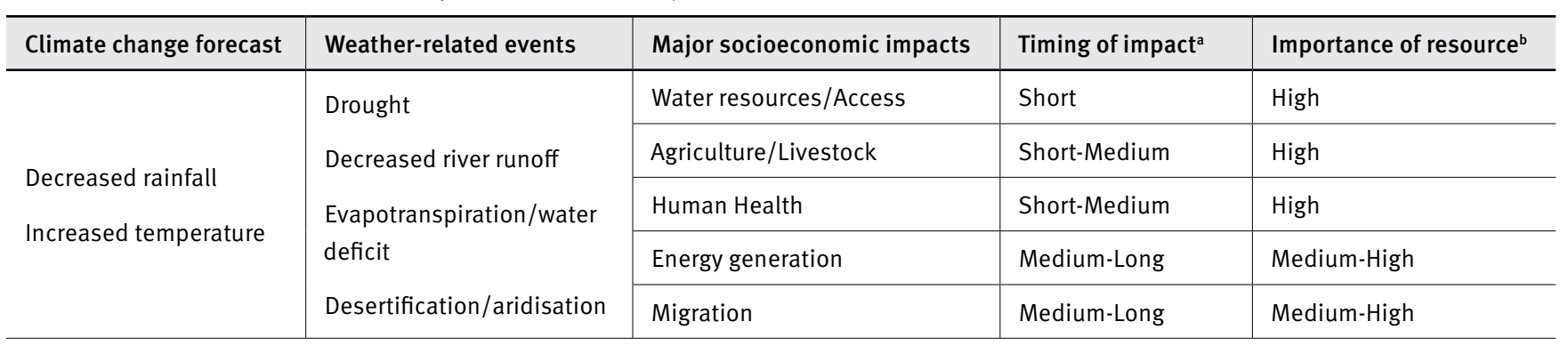

Note: a. Short (2011-2040) - Medium (2041-2070) - Long (2071-2100). b. Importance of resource based on relevance for the socio-economic aspects of the region. Source: Based on Marengo et al., 2012; PBMC, 2013; Interviews.

When it comes to assessing products, services and programmes available, we notice that, broadly, Agroamigo operationalises various public lines of credit under Pronaf. Each line has its own eligibility requirements, interest rates and specific clientele varying according to the sector financed. In addition, according to managers interviewed, about 98\% of Agroamigo's lending programmes are channelled to investment projects. For instance, Pronaf Women and Youth, as well Pronaf Crescer and Mais are aimed at financing employment and income gener- ating activities in agriculture/livestock and, to a lesser extent, non-agricultural sectors. Pronaf Crescer and Mais finance loans for investment and working capital of up to R\$2.500 (US\$1,080) and $R \$ 15.000$ (US\$6,450), respectively, and constitute the vast majority of disbursed lending. Annual interest rates may vary between 0.5 and $3 \%$ and loan terms may last 10 years in some cases.

Pronaf Semiárido provides loans of up to $\mathrm{R} \$ 2.500$ (US\$1,080) at a $1 \%$ annual interest rate destined to financing water systems and drought-tolerant infrastructure. Pronaf Forest 
provides loans of up to $R \$ 15.000$ (US $\$ 6,450$ ) at a $1 \%$ annual interest rate dedicated to environmentally-friendly projects such as tree planting. Other lines include, for example, Pronaf Eco for the financing of techniques that minimise the impact of rural activities on the local environment; Pronaf Agroindústria for investments in micro agro-industries; and, Pronaf Agroecologia for the financing of agro-ecological production and/or organic systems. Through such lending programmes, Agroamigo guarantees credit access to poor smallholder farmers, contributing to enhance their productive capacity and, ultimately, progressive insertion into local markets (Abramovay et al., 2012).

Although there has been an institutional effort to diversify the portfolio towards non-agricultural products, livestock and agricultural activities constitute the great bulk of Agroamigo's lending. In an 8-year time-series, livestock such as dairy cattle has accounted for $79 \%$ of products financed by Agroamigo. Managers as well as coordinators highlighted that albeit actions to nudge income source diversification are in place, the final choice falls onto clients. They also pointed to an intergenerational tradition of livestock production, which is difficult to break. Abramovay et al. (2012), using the Herfindal-Hirschman index to measure the degree of diversification among Agroamigo's clients, noticed a de facto tendency towards livestock activities. In effect, when questioned about diversification of income sources, ten out of twelve clients said they were reticent to change and/or diversify their income generating activities, even if they were offered incentives to do so. Such a tendency could also be explained by the fact that since most clients are beneficiaries of public cash transfer programmes, e.g. Bolsa Família, they do not get incentives to diversify income sources (see, Instituto de Pesquisa Econômica Aplicada, 2013).

Right next are agricultural products totalling $11 \%$ of Agroamigo's financing, with fruit and grain production the vast majority. Other activities include non-agricultural products such as extractivism and services [e.g. tourism, arts and crafts, retail, agro-industry, transportation] and combined constitute $10 \%$ of total 2013's portfolio. In addition, Agroamigo offers savings accounts-according to Abramovay et al. (2012), 40\% of clients save money-, insurance [health and life] schemes, as well as financial and environmental education. All these programmes and products were presented to prospective clients during the informative session attended by the authors.

Disaster relief loans were also implemented in 2012 as an effort to cope with losses clients had faced because of the recent intense drought, namely Pronaf Semiárido 2012. To this regard, national and regional managers stated that the BNB, following a government directive, rescheduled and granted an $80 \%$ bonus on maturing loans for clients living in semiarid zones and allocated about US\$ 1.5 billion in emergency loans to help clients with- stand drought-related losses. At least $50 \%$ of such loans, of up to $\mathrm{R} \$ 2.500$ (US\$1,080) each, were to be directed to financing water wells and more efficient irrigation systems, leaving the remaining 50\% to meet working capital for agricultural/livestock needs.

However, during interviews, two major issues related to the delivery and design of the emergency loans emerged. The first is related to concerns voiced by some interviewees about the lengthy and procrastinated delivery of such emergency loans, which can take months to be actually delivered. Secondly, various interviewees, in particular clients, argued that the amount of each loan was insufficient to cover the full cost of water well construction, which according to them, costs around $\mathrm{R} \$ 3.000$ (US\$1,300).

Agroamigo also seeks to promote synergies between its products and governmental programmes, as for instance, the Programa de Garantia de Preços para a Agricultura Familiar (PGPAF [Guaranteed Price for Smallholder Farmers]), the Programa de Aquisição de Alimentos (PAA [Food Acquisition Programme]), the Programa Nacional de Alimentação Escolar (PNAE [National School Feeding Programme]), the Agricultural Zoning, and crop insurance schemes such as Proagro Mais and Investimento. In addition, it also integrates governmental technical assistance programmes into its pool of products, even though some interviewed managers claimed that there is room for improvement in its provision.

When refined into specific financing categories, as shown in Graphic 1, we observe that the vast majority of Agroamigo's products and programmes, i.e. $71 \%$, fall into activities that generate income and/or employment for clients, either in agricultural/ livestock or non-agricultural sectors. Next are water/disaster relief/preparedness and forestry programmes, accounting for $7 \%$ and $5 \%$, respectively. The remaining categories make up, each, $4 \%$ of total sector programmes. Among these are: education, technical assistance/information transfer, health, and savings schemes.

\section{Graphic 1. Programmes and products financed by Agroamigo by sector categories}

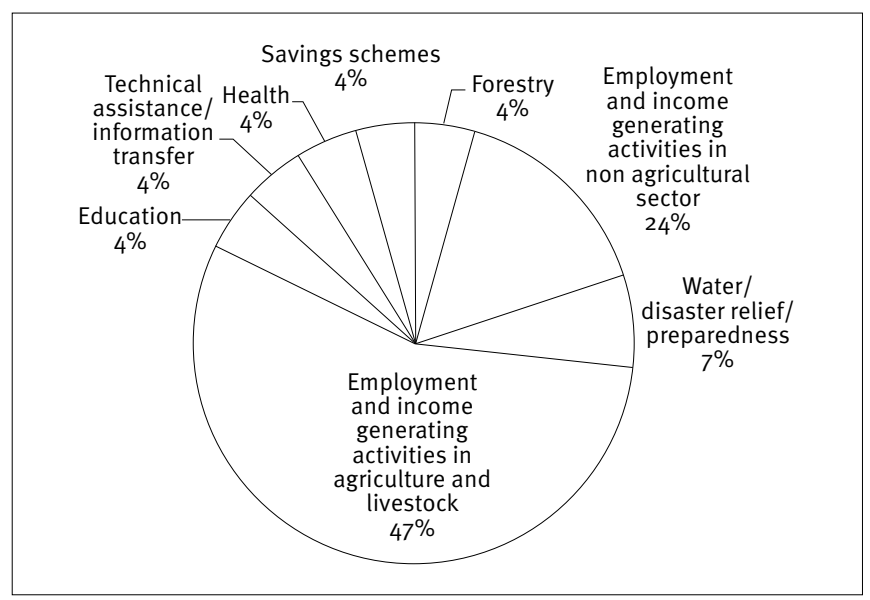




\section{Links to climate change adaptation and mitigation}

At a first look, it emerges that there are important overlaps between products and programmes financed by Agroamigo shown in Graphic 1 and site-specific climate change impacts and vulnerabilities illustrated in Exhibit 1. In particular, agriculture, livestock, health as well as initiatives intended to enhance the resilience of rural communities in the semiarid Northeast [under water/disaster relief/ preparedness] all stand out among Agroamigo's key priorities. A second look, however, shows that links between Agroamigo's products are encompassing and adaptation/mitigation strategies are rather nuanced. As Agrawala and Maëlis (2010) argued, activities that a priori may seem plausible from an adaptation/mitigation perspective may end up increasing climate change vulnerability, and thus, lead to maladaptation. This is because financing activities in sectors which are vulnerable to climate change impacts may entail significant risks both to a MFl's portfolio and its clients, and Agroamigo portfolio's concentration on livestock lending goes exactly in that direction. On the other hand, activities that help rural communities to diversify and generate extra income also contribute to enhance their adaptive capacity, as in the case of most of Agroamigo's lending products. Therefore, 'a more nuanced approach is needed' (Agrawala \& Maëlis, 2010, p. 20).

The amalgamation of Agroamigo's programmes/products and localised climate change vulnerabilities is shown in Graphic 2. Accordingly, $66 \%$ of programmes and products financed by Agroamigo have indirect links with climate change strategies. These include all loans aimed at job creation and income generation both in agricultural, livestock and non-agricultural sectors. Because of their business-induced nature, they contribute to reduce client vulnerability and thus enhance their adaptive ability to cope with climate change. In addition, health/life insurance and savings schemes also fall into this category as they convey coping mechanisms to climate change.

Direct link, in turn, accounts for $12 \%$ of Agroamigo's programmes and products. Among these are programmes dedicated to finance improved water systems, drought-resistant infrastructure, and forestry activities-the Pronaf Semiárido, Pronaf Semiárido 2012, Pronaf Eco, Pronaf Florestal -, crop insurance schemes, e.g. Proagro, as well as technical assistance, environmental education, inputs for biofuel production, and agricultural zoning. Moreover, adaptation activities are the great bulk of Agroamigo's programmes under direct link. These two categories combined constitute what Agrawala and Maëlis (2010) coined "win-win" microfinance programmes, i.e. "programmes which, as currently structured, would automatically contribute to adaptation and [to a lesser extent] mitigation to climate change" (Agrawala \& Maëlis, 2010, p. 21).
Agroamigo's no link programmes and products make up $8 \%$ of the total and include debit card provisions. Lastly, the climate-proofing activities account for $14 \%$ of Agroamigo's products and programmes. These include programmes that need to take better consideration of site-specific climate change vulnerabilities as they may entail significant risk to Agroamigo's financial performance as well as its clients. Although there has been an effort to diversify its lending towards non-agricultural activities, Agroamigo portfolio's concentration on financing cattle production may put its portfolio at greater risk if climatic events such as the 2012-2013 droughts become more frequent and intense in the future. Accordingly, extreme weather events, in particular in the Semiarid Northeast, impact the ability of Agroamigo's borrowers to do business, and the market value of their asset base, which ultimately compromises their ability to service their microloans. By way of example, during the recent drought, the livestock market value in Northeast Brazil fell by $28 \%$, and in certain villages the reduction reached $50 \%$ (Alves, 2012). It occurred more frequently, and in larger scale, in the absence of a sound coping mechanism. Drought-related losses may cause solvency issues to the Programme's portfolio, eventually leading Agroamigo to call on the government for financial leverage.

From a client perspective, on the other hand, such climate-proofing microfinance programmes may lead to maladaptation as the resources these people rely on for their livelihood may be the most sensitive to a changing climate. All twelve interviewed clients stated having already had weather-related losses that affected partially or totally their activities and none of them are insured against such losses. In April 2013, various of Agroamigo's clients from various northeastern states deposited carcasses of cattle, victims of the large-scale drought, outside Agroamigo's branch in the village of Campina Grande, state of Paraiba, in protest for their debts to be written off.

Managers interviewed said that only roughly $2 \%$ of Agroamigo's loans are covered by Proagro policies, leaving most of its portfolio unprotected against eventual climatic shocks. They further argued that this is because Proagro primarily insures working capital for agricultural activities, and since most of Agroamigo's financing is channelled to investments in livestock production, most of its loans remain uncovered by the public insurance scheme. They also argued that in the occurrence of large-scale losses because of extreme weather events, rural trade unions usually call on the government for disaster relief actions. This is precisely what happened during the 2012-2013 drought events where the BNB, following a government's directive, allocated about US $\$ 1.5$ billion in emergency loans, i.e. nearly three time as much as Agroamigo's total outstanding loan portfolio. 
Lastly, although services and products aimed at adaptation and mitigation such as Pronaf Eco, Florestal, and, Agroecologia fall into the direct link category, their share in total Agroamigo lending remains very limited and thus underused. When questioned about this issue, national managers stated that the programme is about to launch a campaign for the 2014 UN's International Year of Smallholder Farmers, namely Agroamigo Sustentável [Sustainable Agroamigo], as an attempt to encourage the use of existing eco-friendly financing mechanisms. Also, the campaign aims at raising awareness on environmentally friendly practices in the pursuit of rural activities. Furthermore, credit agents will be encouraged to strengthen information sharing and best practices on such techniques during informative sessions for current and prospective borrowers.

\section{Graphic 2. Categorisation of links between Agroamigo's products and climate change strategies}

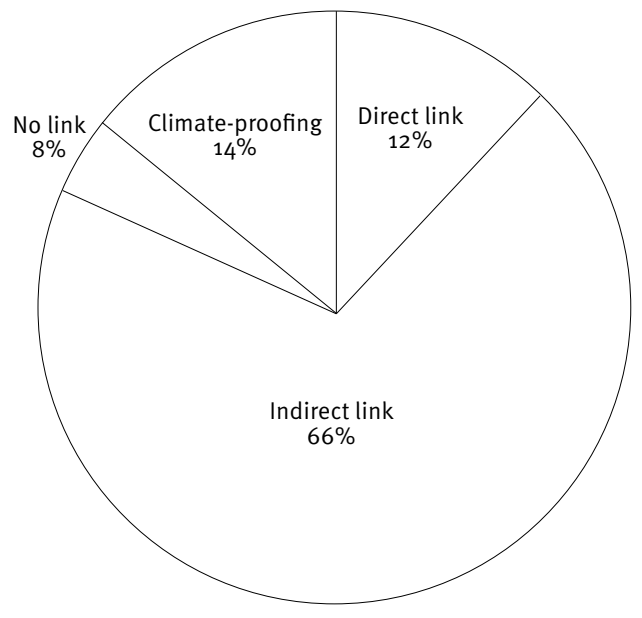

\section{CONCLUSION}

In this study, we sought to show that Agroamigo, Brazil's largest rural microfinance provider, offers important links to climate change initiatives. The focus on the rural poor, who happen to be particularly vulnerable to climate change; its distribution channel covering 10 Brazilian states and reaching out over 800,000 clients; the local knowledge it possesses as well as its ability to help the rural poor generate extra income are all elements that reinforce the broader idea of microfinance as a potential instrument to deliver adaptation and mitigation strategies to the poorest segments of society.
We showed, for instance, that Agroamigo already offers important lending mechanisms that will help clients better respond to climate change impacts, such as saving and insurance schemes, eco-friendly programmes such as the Pronaf Florestal, Pronaf Eco, and Pronaf Semiárido. In addition, the promotion of sustainable development, imbued in Agroamigo's mission, and its environmental literacy education represent an important step towards the adoption of a triple bottom line approach [people, planet, profit]. Also, disaster relief loans, flexible repayments and bonuses and rescheduling on maturing loans during the 20122013 large-scale droughts were considered very satisfactory by interviewed clients and credit agents. Besides, at the institutional level, Agroamigo already promotes an environmentally friendly approach to business by reducing its ecological footprint, e.g. reducing waste and paper use.

Nevertheless, in light of pertinent literature on green microfinance, climate vulnerabilities, analysed and transcribed interview data, field observation and relevant documents, we believe that programmes and products offered by Agroamigo can be enhanced to take better consideration of localised climate change vulnerabilities. Therefore, our recommendations are as follows:

Recommendation 1: we suggest that Agroamigo consider applying a climate change lens to its products and embark on a more proactive role to consider risks and vulnerabilities stemming from global warming better, particularly water resources. For instance, greater effort towards portfolio diversification could be enhanced, in particular towards non-agricultural lending and drought-tolerant crops; and here, Agroamigo's credit agents are placed in a strategic position to circumvent local tradition in livestock production and nudge clients towards the diversification of income sources. Agier (2012), for example, showed the potential of credit agent abilities in the microcredit cycle, in particular at the screening stage. Moreover, loans for acquisition of more efficient irrigation/water technologies were retained by clients and credit agents as insufficient to cover the full cost and, therefore, could be revisited by Agroamigo. There is also room for improvement in technical assistance provisions.

Recommendation 2: we suggest extending insurance schemes to areas not covered by the Proagro, for instance, livestock investment projects. At present, roughly $2 \%$ of Agroamigo's outstanding loans are insured against climate-related losses via Proagro policies. This is because such a scheme primarily insures working capital to meet agricultural production needs, and most of Agroamigo's lending is channelled to livestock purposes, leaving its portfolio and clients unprotected against weather shocks. A solution could be implementing index-based insurance schemes, considered a prominent tool in the green microfinance sector, to 
serve as a complement to the government's Proagro, especially in not-covered areas such as livestock investment projects. These are insurance schemes which are triggered according to established local weather thresholds, or indexes, and thus, avoid problems related to individual misbehaviour and costly harvest loss assessments (see, for example, Wang, Karuaihe, Young, \& Zhan, 2013).

Recommendation 3: we suggest that more room for manoeuvre be given to Agroamigo administration in the design and planning of products and programmes. This is because the programme has institutional and legal constraints in planning and designing programmes, services and products. More specifically, Agroamigo operationalises various public credit lines and thus acts upon governmental instructions and directives. If extreme weather events occur with more frequency and intensity in the future, such excessive reliance on the government may hinder Agroamigo's ability to deliver ready and quick disaster relief responses, and thus, may exacerbate the climate change burden on the business performance of clients. In fact, a major concern voiced by some interviewees was the lengthy delivery of disaster relief programmes.

Recommendation 4: we believe that there is room for Agroamigo to foster mitigation strategies, which, at present, remain virtually unexplored. Abramovay et al. (2012) claims that although most clients have access to electric power, $40 \%$ of them use coal or wood burning stoves. Therefore, renewable energy sources such as biodigesters and improved cooking stoves beyond constituting a new market opportunity for Agroamigo can be financed through existing tools such as the Pronaf Eco. To this regard, the campaign Agroamigo Sustentável may work in that direction. In addition, Agroamigo may consider engaging in the Mecanismo de Desenvolvimento Limpo (Clean Development Mechanism), the international voluntary market, and/or partner [e.g. energy suppliers, intermediary organisations] to finance mitigation initiatives.

Nevertheless, we also acknowledge there are trade-offs in promoting a green microfinance industry by Agroamigo. For example, finding the balance between shorter-term livelihood needs of Agroamigo clients and the longer-term commitments needed for adaptation and mitigation may represent a major constraint in fostering climate change actions. Moreover, in some cases, Agroamigo's loans may increase the debt burden of borrowers, placing added pressure on their adaptive ability. Also, climate change actions at the customer/institutional level may entail risks for Agroamigo's portfolio. Lastly, “climate proofing” Agroamigo would require additional employee skills, in particular to coordinators and credit agents, which may increase administration costs. Therefore, Agroamigo, in responding to climate change, will need to weigh the balance between costs and benefits entailed in fostering adaptation and mitigation strategies, and be aware that its actions in this arena are certainly no panacea.

More research is needed to understand the actual design and implementation of our recommendations better, though. Yet, there is a unique study on green microfinance that we believe will constitute a relevant empirical contribution to such an incipient realm. In addition, with our study, we hope to encourage Brazilian academia to investigate this contemporary, and yet overlooked, pressing domain further.

\section{REFERENCES}

Abramovay, R., Rodrigues Jr., M., Madeira, G., Gonçalves, M., Maciel, I. S. R., Santos, R. A. dos. (Orgs). (2012). Cinco anos de Agroamigo: Retrato público e efeitos do programa. Fortaleza: Banco do Nordeste do Brasil.

Agier, I. (2012). The role of credit officers in the performance of micro loans: Evidence from Brazil. Economics of Transition, 20(2), 271-297. doi:10.1111/j.1468-0351.2012.00434.x

Agrawala, S., \& Maëlis, C. (Org.). (2010). Assessing the role of microfinance in fostering adaptation to climate change [Working Paper N. 15]. OECD Environmental, Paris.

Ahmed, S. A., Diffenbaugh, N. S., \& Hertel, T. W. (2009). Climate volatility deepens poverty vulnerability in developing countries. Environmental Research Letters, 4(3), 1-8. doi:10.1088/17489326/4/3/034004

Allet, M., \& Hudon, M. (2013). Green microfinance: Characteristics of microfinance institutions involved in environmental management. Journal of Business Ethics, 126(3), 395-414. doi:10.1007/s10551-0131942-5

Alves, A. C. (2012). Crise na pecuária: Seca reduz preço do gado em 28\%. Diário do Nordeste-eletrônico. Retrieved from http:// diariodonordeste.verdesmares.com.br/cadernos/regional/secareduz-preco-do-gado-em-28-1.417804

Instituto de Pesquisa Econômica Aplicada. (2013). Caracterização do público potencial do Pronaf B na região nordeste e no estado de Minas Gerais: Uma análise baseada nos dados do Censo Agropecuário 2006. Brasília: Instituto de Pesquisa Econômica Aplicada.

Baettig, M., Wild, M., \& Imboden, M. (2007). A climate change index: Where climate change may be most prominent in the 21st century. Geophysical Research Letters, 34(1), 1-6. doi:10.1029/2006glo28159

Banco do Nordeste. (2013). Relatório 2012 Agroamigo. Fortaleza: Banco do Nordeste.

Berg, B. L. (2004). Qualitative research methods for the social sciences. Boston: Pearson.

Bretschger, L., \& Valente, S. (2011). Climate change and uneven development. The Scandinavian Journal of Economics, 113(4), 825845. doi:10.1111/j.1467-9442.2011.01676.x

Brooke, C. (2008). Conservation and adaptation to climate change. Conservation Biology Journal, 22(6), 1471-1476. doi:10.1111/j.15231739.2008.01031.x 
Centro Universitário de Estudos e Pesquisas sobre DesastresUniversidade Federal de Santa Catarina. (2012). Atlas brasileiro de desastres naturais 1990-2010. Volume Brasil. Florianópolis: CEPEDUFSC.

Cull, R., Demirgüç-Kunt, A., \& Morduch, J. (2009). Microfinance meets the market. Journal of Economic Perspectives, 23(1), 167-192.

Dowla, A. (2009). Climate change and microfinance. Washington: Grameen Foundation.

Forcella, D. (2011). Preliminary assessment microinsurance facility for climate change adaptation. Save the Earth Cambodia.

Gonzalez, L., Piza, C. T., \& Garcia, D. B. (2009). Sinergia entre microsseguro e microcrédito e o crescimento dos mercados no Brasil. Revista Brasileira de Risco e Seguro, 5(10), 45-84.

Hall, J., Collins, L., Israel, E. \& Wenner, M. (2008). The missing bottom line: Microfinance and the environment. Washington, DC, The SEEP Network Social Performance Working Group Social Performance MAP.

Hammill, A., Matthew, R. \& McCarter, E. (2008). Microfinance and climate change adaptation. IDS Bulletin, Institute of Development Studies, 39(4), 113-122. doi:10.1111/j.1759-5436.2008.tboo484.x

Intergovernmental Panel on Climate Change. (2013). Climate change 2013: The physical science basis. Contribution of Working Group I to the Assessment Report of the Intergovernmental Panel on Climate Change, Cambridge University Press, Cambridge, 5.

Littlefield, E., Morduch, J., \& Hashemi, S. (2003). Is microfinance an effective strategy to reach the Millennium Development Goals? Focus Note, 24, 1-11.

Loiselle, Bette A., Graham, Catherine H., Goerck, J. M., \& Ribeiro, M. C. (2010). Assessing the impact of deforestation and climate change on the range size and environmental niche of bird species in Atlantic forests, Brazil. Journal of Biogeography, 37(7), 1288-1301. doi:10.1111/j.1365-2699.2010.02285.x

Majumber, A. (2009, August 18). Bangladesh's rural poor tap the power of the sun. International Herald Tribune, $18^{\text {th }}$ August 2009.

Marengo, J. A., Jones, R., Alves, L. M. \& Valverde, M. C (2009). Future change of temperature and precipitation extremes in South America as derived from the PRECIS regional climate modelling system. International Journal of Climatology, 29(15), 2241-2255. doi:10.1002/ joc. 1863

Marengo, J. A., Chou, S. C., Kay, G., Alves, L. M., Pesquero, J. F., Soares, W. R., ... \& Tavares, P. (2012). Development of regional future climate change scenarios in South America using the Eta CPTEC/HadCM 3 climate change projections: Climatology and regional analyses for the Amazon, São Francisco and the Paraná River basins. Climate Dynamics, 38(9-10), 1829-1848. doi:10.1007/s00382-011-1155-5

Marengo, J. A., \& Valverde, M. C. (2007). Caracterização do clima no século XX e cenário de mudanças de clima para o Brasil no século XXI usando os modelos do IPCC-AR4. Revista Multiciência, 8, 5-28.

McKee, K. (2008). Microfinance: climate change connections. Development Outreach, 10(1), 35-37. doi:10.1596/1020-797X-10-1_35

Mix Market. (2014). Database. Retrieved from http://www.mixmarket. org/mfi/country/Brazil

Moran-Ellis, J., Alexander, V. D., Cronin, A., Dickinson, M., Fielding, J., Sleney, J., \& Thomas, H. (2006). Triangulation and integration: Processes, claims and implications. Qualitative Research, 6(1), 4559. doi:10.1177/1468794106058870
Muehe, D. (Ed.). (2006). Erosão e progradação do litoral brasileiro. Brasília: Ministério do Meio Ambiente.

Painel Brasileiro de Mudanças Climáticas. (2013). Sumário executivo do volume 1 - base científica das mudanças climáticas. Contribuição do Grupo de Trabalho 1 para o Relatório de Avaliação Nacional do Painel Brasileiro de Mudanças Climáticas, Volume Especial para a Rio+20, Rio de Janeiro, 1.

Rippey, P. (2012). Microfinance and climate change: Threats and opportunities. In Greening the Financial Sector (pp. 215-239). Berlin: Springer Berlin Heidelberg.

Schellnhuber, H. J., Hare, B., Serdeczny, O., Schaeffer, M., Adams, S., Baarsch, F. \& Rocha, M. (2013). Turn down the heat: Climate extremes, regional impacts, and the case for resilience. Washington, DC: World Bank.

Serviço Brasileiro de Apoio às Micro e Pequenas Empresas. (2010). Inclusão financeira. Brasília: SEBRAE. Retrieved from http:// www.agenciasebrae.com.br/noticia/10965415/economia/paraorganizacoes-internacionais-microfinancas-tem-grande-potencialde-crescimento-no-brasil/

Sistema de Estimativa de Emissões de Gases de Efeito Estufa (2014). Database. Retrieved from http://seeg.observatoriodoclima.eco.br/ index.php/page/17-Emiss\%25C3\%25B5es-por-setor

Silva, B. D., Braga, A. C., Braga, C. C., Oliveira, L. D., Galvíncio, J. D., \& Montenegro, S. M. G. L (2012). Evapotranspiração e estimativa da água consumida em perímetro irrigado do Semiárido brasileiro por sensoriamento remoto. Pesquisa Agropecuaria Brasileira, 47(9), $1218-1226$

Stake, R. E. (1995). The art of case study research. Thousand Oaks, CA: Sage.

Stake, R. E. (2005). Qualitative case studies. In N. K. Denzin \& Y. S. Lincoln (Eds.), The Sage handbook of qualitative research ( ${ }^{\text {rd }}$ ed., pp. 443-466). Thousand Oaks, CA: Sage.

Stern, N. (2007). The economics of climate change: The Stern Review. Cambridge: Cambridge University Press.

Taylor, M. (2012). The antinomies of 'financial inclusion': Debt, distress and the workings of Indian microfinance. Journal of Agrarian Change, 12(4), 601-610. doi:10.1111/j.1471-0366.2012.00377.x

Teixeira, M. (2013, November 7). Brazil greenhouse gas emissions down 4.9 pct in 2012. Reuters, São Paulo. Retrived from http://www.reuters.com/

United Nations. (2013). Pior seca dos últimos 50 anos no nordeste brasileiro confirma estatísticas da ONU sobre escassez. Retrieved from http://www.onu.org.br/pior-seca-dos-ultimos-50-anos-no-nordestebrasileiro-confirma-estatisticas-da-onu-sobre-escassez/

United States Agency for International Development. (2009). Microfinance and climate change: can mfis promote environmental sustainability? Washington: USAID.

Vijayavenkataraman, S., Iniyan, S., \& Goic, R. (2012). A review of climate change, mitigation and adaptation. Renewable and Sustainable Energy Reviews, 16(1), 878-897. doi:10.1016/j.rser.2011.09.009

Wang, H. H., Karuaihe, R. N., Young, D. L., \& Zhang, Y. (2013). Farmers' demand for weather-based crop insurance contracts: The case of maize in South Africa. Agrekon: Agricultural Economics Research, Policy and Practice in Southern Africa, 52(1), 87-110. doi:10.1080/0 3031853.2013.778468

Warth, A. (2014, February 19). Térmicas superam hidrelétricas no Nordeste. O Estado de S. Paulo. Retrieved from http://www.estadao. com.br/ 